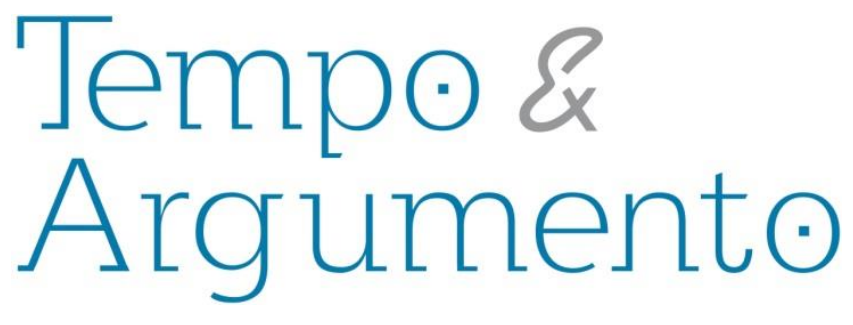

\title{
Imagens em fuga: considerações sobre espaço público visual no tempo presente
}

\section{Resumo}

Este artigo trabalha com a noção de fotografia pública, seus circuitos sociais, usos e funções em perspectiva histórica. Analisam-se as posições em jogo no debate historiográfico sobre imagem pública e observam-se os percursos das imagens no espaço público visual na modernidade em seus deslocamentos do século XX para o XXI, tomando a fotografia como meio para essa viagem. Apresenta-se em dois estudos de caso para reflexão sobre a metamorfose da imagem no espaço público visual e seu potencial político.

Palavras-chave: Fotografia Pública. Espaço Público.

Cultura Visual.

\section{Ana Maria Mauad}

Doutora em História pela Universidade Federal Fluminense - UFF. Celso Furtado Visiting Scholar, Cambridge University, UK. Professora Titular do Departamento de História da Universidade Federal Fluminense - UFF. Niterói - RJ - BRASIL anammauad@gmail.com

\section{Para citar este artigo:}

MAUAD, Ana Maria. Imagens em fuga: considerações sobre espaço público visual no tempo presente. Tempo e Argumento, Florianópolis, v. 10, n. 23, p. 252 - 285, jan./mar. 2018. 


\title{
Images on the road: considerations on visual public space at present time
}

\begin{abstract}
The article deals with the notion of public photography, its social circuits, uses and functions in historical perspective. It is analyzed the different positions in the historiographical debate about public image and it is observed the itineraries of the images in the visual public space of modernity in their movement from twentieth century to the twentieth one, taking photography as a medium for this trip. Two study cases are presented to reflect the transformation of the image in the visual public space and their political potential.
\end{abstract}

Keywords: Public Photography. Public Space.

Visual Culture.

Em 2015, fui convidada para falar no Encontro de Inclusão Visual, realizado no Museu de Arte do Rio (MAR), no âmbito do FotoRio, sobre fotografia e história. Durante a pesquisa para montar a série de fotografias para a palestra, deparei-me com um conjunto de imagens de Getúlio Vargas que, simplesmente, me cativaram. A busca despretensiosa e ilustrativa para compor a série denominada - O poder em foco - acabou sendo guiada pelo gosto de ver a imagem do presidente em plena performance de poder, como se recordasse cenas já vividas. As datas não eram precisas e a série, por fim, foi organizada cronologicamente pelo aspecto físico do presidente, principalmente, pelas marcas de seu envelhecimento.

Confesso que minhas escolhas foram conduzidas pelas próprias imagens que, saltavam do mosaico criado pelo Google imagens, como recordações quase familiares. Destacam-se pelas atitudes, sorrisos, acenos, abraços, trejeitos; pela indumentária, corte 
do terno, diferentes modelos de chapéus, enfim, um repertório de signos que caracterizam o poder em cena, aspectos de uma cultura política que se forjava então. Me dei conta de que as fotografias de Getúlio Vargas, produzidas na época em que se tornou uma figura pública - Revolução de 1930, Estado Novo e período democrático (1930-1954) - e que ainda circulam na web, criam aquilo que Ulpiano Bezerra de Meneses (2003) chamou de iconosfera. Uma atmosfera de ícones composta por imagens visuais de natureza diversa que fundamentam os modos de ver, dar a ver e tornar visível aspectos de uma sociedade, uma visualidade compartilhada pelos meios em que as imagens se aderem.
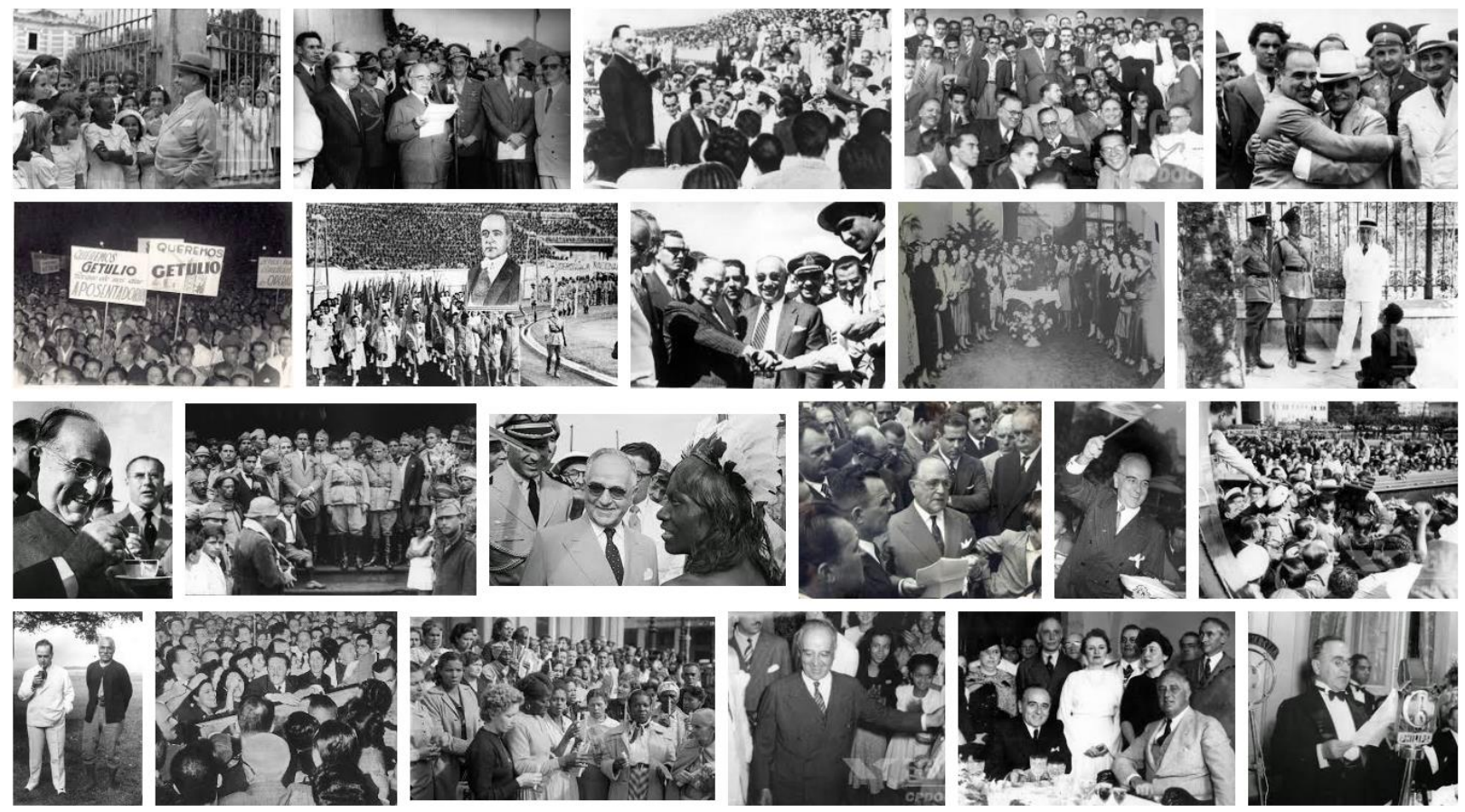

Fig.1: Captura de tela do Google Imagens - palavra-chave - Getúlio Vargas. Acesso em: 14/12/2017.

Associadas à publicização da imagem do presidente, quer seja pelas agências de governo, como o Departamento de Imprensa e Propaganda (DIP), quer seja pelas revistas ilustradas em que eram veiculadas, essas fotografias pavimentaram o espaço público visual associado às performances do poder político. Corresponderam às demandas de uma cultura política que se massificava face ao crescente número de eleitores e espectadores do jogo de poder. A sequência de imagens de Getúlio Vargas provocou-me 
As considerações em torno da elaboração de um espaço público visual associam-se à existência de uma cultura visual em que os meios de produzir imagens, fixas e em movimento, não só criam representações sobre o mundo visível, em um movimento de dar a ver e de conhecer o mundo representado em imagens, mas instituem, elas mesmas, a visibilidade do mundo por meio de imagens. Entretanto, há que se avaliar as dimensões históricas das culturas visuais e as economias de trocas simbólicas que se estabelecem entre os diferentes grupos sociais, para compreendermos as formas que esse espaço público visual assumiu ao longo do tempo e na atualidade.

Embalado pelo debate sobre a história pública no Brasil, este artigo investe na noção de fotografia pública, seus usos e funções em perspectiva histórica. Busca-se identificar as posições em jogo no debate historiográfico sobre imagem pública, para na sequência, observar os percursos das imagens no espaço público visual na modernidade em seus deslocamentos do século XX para o XXI, tomando a fotografia como meio para essa viagem. Nesse itinerário, a noção de público associa-se às experiências contemporâneas com imagens e por meio das imagens, incorporando as ideias de audiência, espectador e agente, mas também de espaço e de lugar. Os debates em torno da fotografia pública e do espaço público visual estão, indefectivelmente, ligados à condição histórica do capitalismo avançado e à constituição do tecido político democrático no mundo contemporâneo.

\section{Imagem pública em perspectiva historiográfica}

$\mathrm{Na}$ cultura visual própria à modernidade de natureza intermedial, as imagens técnicas migram da fotografia para o cinema, das páginas das llustradas para as propagandas governamentais, dos jornais diários para as assessorias de imprensa, dos relatórios científicos para as reportagens fotográficas, dos registros documentais para a ficção. Os circuitos sociais de produção, circulação, consumo e agenciamento das 
imagens técnicas - fotográficas, cinematográficas e videográficas -, da cultura visual nos novecentos, orientaram conformações possíveis para o espaço público visual, ainda presentes nessa primeira metade do século XXI.

As características desse espaço são marcadamente políticas e estabelecem as conexões entre cultura visual e cultura política nas sociedades ocidentais. Nas configurações políticas que o espaço público visual assumiu, ao longo do século XX e início do XXI, afastou-se da clássica oposição entre o público e privado, para se aproximar de uma dimensão do público como aquilo que é comum a um grupo, a uma classe, a um gênero, etc. As disputas em torno da ocupação dos espaços públicos visuais, bem como a tentativa de impor um sentido comum arbitrado somente por um dos grupos, fazem parte da guerra de imagens que o mundo contemporâneo ainda trava.

Nessa guerra, montam-se trincheiras em torno do papel da imagem pública no mundo contemporâneo, em especial, o fotojornalismo e a fotografia documental ${ }^{1}$. De um dos lados do debate, os que assumem uma perspectiva crítica em relação à forma de operar fotograficamente na cultura política da democracia liberal (TAGG, 1982, 1988; SEKULLA, 1982; BURGIN, 1982; FLUSSER, 2000), e do outro, os que defendem uma leitura liberal da dimensão política do espaço público visual. A polêmica central confronta aqueles que atribuem à imagem fotográfica o poder de produzir sentido social e os que renunciam ao peso da representação que a fotografia pública carrega em prol da defesa de um espectador cidadão e de uma audiência cidadã (KRAUSS, 1990; HARIMAN \& LUCAITES, 2016; BATCHEN, 2004).

As variações em torno de ambos os lados dessa disputa merecem ser consideradas com cuidado para se evitar visões dicotômicas, pouco produtivas para a compreensão

\footnotetext{
${ }^{1}$ A diferença entre fotojornalismo e fotografia documental estabelece-se em função de alguns aspectos: o tema e a forma de circunscrevê-lo temporalmente pela narrativa fotográfica; nesse aspecto, prática do fotojornalismo, volta-se para a cobertura de acontecimentos, enquanto a prática fotográfica documental estaria associada a questões e processos de média a longa duração. Embora fotojornalistas possam realizar registros fotográficos documentais, a especialização da prática fotográfica, ao longo do século XX, orientou o estabelecimento de formas de ação distintas e estreitamente relacionadas ao financiamento de projetos documentais, de defesa do direito autoral e de guarda do arquivo fotográfico resultante da experiência. Ambos, entretanto, seriam considerados expressão daquilo que Olivier Lugon (2010) denominou de 'estilo documental'. Sobre o debate entre as duas práticas, cf. Newhall, 1984; Ritchin, 2013; Strauss, 2003; Linfield, 2010.
} 

fotografia; no segundo, as dimensões éticas e políticas associam-se ao que a fotografia habilita e ao que ela interdita em seus usos públicos contemporâneos; e um terceiro, de caráter metodológico, coloca em evidência uma tendência dos trabalhos sobre fotografia produzidos no início do século XXI: a valorização do foto-ícone em relação ao tratamento de séries fotográficas.

A fotografia como campo de reflexão consolidou, ao longo do século $X X$, uma grande narrativa apoiada nos parâmetros de uma história da técnica e dos estilos fotográficos. Em que pese a contribuição do inventário das técnicas e das retóricas associadas a gêneros e autores consagrados, tal abordagem não deu conta da fotografia como dimensão pública da experiência humana, bem como da variedade de seus engajamentos em ambientes socioculturais diversos. Desde o início dos anos 1980, com a emergência dos "estudos visuais" e da "nova história da arte", esta reflexão extravasou os limites das ontologias modernas e dos paradigmas tradicionais da história da arte. Um amplo projeto de revisão da história canônica da fotografia - precipitadamente associado à "condição pós-moderna" (BATCHEN, 2004, cap. 1) - mobilizou um conjunto de autores que, longe de se limitar a um único campo disciplinar, buscou novos caminhos para a crítica e a teoria fotográficas em contextos mais amplos como os da história da imagem, dos estudos de mídia e de cultura visual, da filosofia política e da antropologia póscolonial (KRIEBEL, 2007).

Em 1980, Alan Trachtemberg publicou uma célebre antologia chamada Classic Essays on Photography, que se encerrava com ensaios de Roland Barthes e John Berger. Ao panteão dos clássicos, poderíamos acrescentar Susan Sontag (1977), no seu seminal On Photography, um dos primeiros textos críticos a levantar questões éticas e políticas sobre o fotojornalismo e fotografia documental. Uma abordagem retrospectiva sobre o estado da arte nos estudos sobre a imagem pública foi proposta por Hariman e Lucaites (2016): 


\begin{abstract}
We are not alone in attempting to see photography anew. Photography theory today is in a state of flux; we could say that is tending in the direction we are taking, but time will have to tell. What can be said is that a shift in interpretative community is beginning to emerge. The older paradigm was defined on several sides by Frankfurt School (e.g., Siegfried Kracauer, Walter Benjamin, Bertold Brecht, Theodore Adorno, Max Horkheimer); by Sontag and others channeling an iconoclastic critical attitude (e.g., Roland Barthe, Guy Debord, Allan Sekula, John Berger, John Tagg, Victor Burgin, Rosalind Krauss, Abigail SolomonGodeau, Martha Rosler, Carol Squires, and the thousands of scholars who extended the work of the Birmingham School of Cultural Studies). [...] The more recent [interpretative] community, which itself will continue to evolve, includes historians, critics, and theorists. (HARIMAN \& LUCAITES, 2016, p. 6)
\end{abstract}

Na linha de abordagem da dupla de autores, se observaria nos estudos teóricos sobre fotografia, na virada do século XX para o XXI, uma mudança de paradigma. Na linha de Thomas Khun, os autores consideram que:

Any program of collaborative learning depends on a shared conception of the object and method of study, a common set of problems to be solved, and assumptions about what needs to be said and what need not to be said. As time passes, however, there arise significant irregularities and incongruities that cannot be accounted for adequately within the standard model. (HARIMAN \& LUCAITES, 2016, p. 7)

O processo de mudança, segundo os autores, não configuraria uma revolução com rupturas bruscas, seria sim uma evolução do conhecimento. Um processo de superação do pensamento anterior em prol de um mais bem-acabado, o que levaria os representantes desse pensamento anterior, ao tentarem se atualizar nas novas modalidades de reflexão, a caírem na armadilha da linguagem e nos pressupostos enraizados na moldura convencional. Essa linha de análise acaba por determinar o fim da noção de crítica, controvérsia e polêmica, em prol de um pensamento linear e conformado por etapas. Conclui-se por essa linha de análise que a abordagem liberal adotada por Hariman e Lucaites seria a superação tanto do marxismo ocidental, quanto do pensamento crítico do pós-estruturalismo, considerados simplesmente ultrapassados.

$\mathrm{Na}$ discussão proposta pelos autores em suas obras sobre imagem pública, destacam-se as contribuições associadas à noção de foto-ícones, ao destaque para emergência de novas tecnologias de visualização da fotografia e à crítica à 
sobrevalorização da natureza dissimulada da imagem, pelos estudos da década de 1970. Entretanto, em seus desdobramentos, a compreensão de que os modos de ver na democracia, necessariamente, criariam a demanda por um espectador emancipado e, ainda, habilitariam a cidadania no espaço público visual, não avançam no debate teórico limitado pela retórica liberal.

O quadro de 'paradigmas' apresentados pelos autores possui, no entanto, uma vantagem heurística, pois definem linhas de reflexão que tencionam no debate sobre a fortuna crítica da fotografia. Melhor seria convocar a noção de virada pictórica - 'pictorial turn' - apresentada por W. J. T. Mitchell para dimensionar o rearranjo epistemológico ocorrido nos estudos sobre fotografia na virada do milênio. Por virada pictórica, Mitchell atribui uma figura de linguagem que vem sendo acionada desde a Antiguidade, não se tratando de um fenômeno exclusivamente atual: "A critical and historical use of this figure would be as a diagnostic tool to analyze specific moments when a medium, a technical invention, or cultural practice erupts in symptoms of panic or euphoria (usually both) about 'the visual"' (MITCHELL, 2005, p. 349).

Mitchell completa explicando que momentos de descoberta de uma nova forma de imagem - da fotografia, por exemplo - delineiam uma virada histórica e a configuração de novas constelações interpretativas. Talvez, diante da ameaça dos discursos do fim da fotografia, com o surgimento da imagem numérica ou digital, os estudos sobre o assunto tenham se deslocado para novas configurações sobre os usos e funções da imagem pública. O que nos leva para o segundo aspecto do debate.

O gradual engajamento político do fotojornalismo, ao longo do século $\mathrm{XX}$, com o surgimento das agências independentes, como a francesa Magnun; a luta pelo reconhecimento, por parte dos fotógrafos de imprensa, do valor da suas imagens como meio de produzir notícias e; a definição de uma agenda para o fotojornalismo, com pautas voltadas para a cobertura de guerras, revoluções, catástrofes etc., com recursos tecnológicos para a transmissão da imagem e do reconhecimento profissional, permitiu ao mundo aceder a tais acontecimentos por meio das imagens fotográficas que circulavam em jornais e revistas em todas as partes (SOUSA, 2000). 
A guerra do Vietnã talvez tenha sido a batalha final desse tipo de fotojornalismo engajado na apresentação dos múltiplos ângulos dos fatos, comprometidos com mostrar, denunciar e mobilizar. Compromisso presente também na prática da fotografia documental voltada para o registro de populações inteiras em situações-limites. A experiência fotográfica que marcou a segunda metade do século XX geraria nos estudos sobre fotografia um poderoso debate ético: o direito de fotografar e o direito de não ser fotografado. Como o debate envolve um fôlego maior do que o desse artigo, vale apresentar dois estudos em que essas posições são consideradas.

Em sua original reflexão, Ariella Azoulay $(2010,2012)$ apresenta a possibilidade da fotografia moderna orientar um novo tipo de contrato social: o contrato civil da fotografia. Segundo a autora:

The civil contract of photography can be extracted from existing photographic practices and uses, but is irreducible to any of them, nor can it be depicted as a product if their accumulation. Rather, positing this contract is a way to delineate part of the newly constructed space of civil relations that has been opened - and even necessitated - by photography. [...] Briefly put, the camera modified the way in which individuals are governed and the extent of their in the forms of governance. It is that change that I explore. (AZOULAY,2010, p. 89)

Um contrato que se estabelece entre o fotógrafo e o fotografado e tem no público o fiador da imagem. O contrato civil da fotografia apoia-se na experiência continuada do fotografado oferecer a sua imagem ao fotógrafo e reclamar a sua existência. Azoulay convoca a participação do espectador, do público, como instância regulamentadora do contrato civil da fotografia. Esse seria o responsável por afiançar o contrato entre as partes - fotógrafo e fotografado - ao animar a fotografia com o seu olhar. O espectador faz valer a cidadania fotográfica, identificando a ação que gerou os 'objetos-fotografias' e o 'evento fotográfico'. Portanto, o contrato social da fotografia tem no espectador o seu fiador, cuja responsabilidade ética seria a de não isolar a fotografia da experiência que a funda - o evento da fotografia - situações, que mesmo não sendo fotografadas, integram o território da fotografia. 
O contrato social da fotografia garantiria o direito de ser fotografado. Sobre esse direito, Azoulay relata o caso de uma senhora palestina, Abu-Zohir, que chamou a imprensa para fotografar as marcas das balas de borracha em suas pernas. Ao chegar à sua casa, o fotógrafo e a repórter se confrontaram com a seguinte situação: a senhora Abu-Zohir queria ser fotografada sem a presença do fotógrafo, pois não iria mostras suas pernas em público, somente, reservadamente, para a sua filha. Exigência que levou o fotógrafo a montar sua câmera e a deixar preparada para o disparo pela filha da senhora. No livro de Azoulay, vemos a foto da senhora Abu-Zohir, com o vestido levemente levantado, deixando à mostra as marcas roxas na perna resultantes das balas de borracha e ao lado dela a silhueta da filha. O que levou a senhora Abu-Zohir a acreditar na capacidade da fotografia em mostrar e se transformar em um reclamo de uma demanda, foi a crença no acordo e na convenção da fotografia. Acordo consumado de fato pelo uso da imagem no livro de Azoulay que fez com que nós, os espectadores/leitores, afiançássemos o contrato.

O historiador Kevin Coleman (2015), por sua vez, conta o interessante caso do camponês hondurenho que não quis ser fotografado. Em 1953, a revista Life enviou a sua repórter e fotógrafa mundialmente reconhecida, Margaret Bourke-White, para as montanhas da Mesoamérica, com o objetivo de realizar uma completa cobertura fotográfica das missões religiosas na região. Entretanto, a sua sanha fotográfica de tudo registrar, considerando, sobretudo, as situações inusitadas e pitorescas, bem do gosto do público da revista, tropeçou na resistência de um homem humilde em ser fotografado. Coleman examina, em seu texto, a determinação desse homem que reclamou para si o direito de ser deixado à margem da câmera, argumentando que as teorizações sobre o "contrato civil da fotografia" e o "direito a ver" necessitam ser moderadas por meio da tradicional defesa do direito à privacidade e pela urgente preocupação contemporânea com a invasão eletrônica dos governos e de empresas em nossas vidas.

O ensaio polemiza a proposta de Azoulay em que o contrato civil da fotografia garante que todos têm o direito a ser fotografado e que o fotógrafo tem como dever comunicar e informar. Entretanto, em suas considerações, Coleman acabar por seguir a linha de análise de Azoulay, ao concluir que a negação do camponês o reinscreve no 
contrato social da fotografia, justamente, por não querer ser fotografado seria integrado ao território da fotografia - no caso específico desse camponês apoiado na crença de que a fotografia roubaria a sua alma. Compreende, portanto, a fotografia como ação que se processa não somente com a tomada da foto, mas sobretudo, pela percepção do evento da fotografia.

De acordo com essa linha de reflexão, a fotografia se confirmaria como base da imaginação civil, orientando-se para a terceira característica dos estudos contemporâneos, a valorização da fotografia única ou foto-ícone.

A análise de fotografias exemplares de situações históricas foi ganhando terreno em relação ao estudo de séries longas e homogêneas que fundamentaram as análises histórico-semióticas do final do século XX. Em sintonia com a virada epistemológica já mencionada, os estudos históricos com fotografias passaram do uso do meio como fonte e objeto da história para fotografias como agentes da história (MAUAD, 2016). Um movimento que evidencia o deslocamento de análises de viés estruturalista em que o fundamental seria decodificar os sentidos transmitidos pela mensagem fotográfica, em prol de atitudes interpretativas em estreito diálogo com os estudos sobre cultura visual e história visual que se consolidaram no início do século XXI (Meneses, 2003 e Knauss, 2006).

No Brasil, a publicação do artigo "A fotografia como documento - Robert Capa e o miliciano abatido na Espanha: sugestões para um estudo histórico", por Ulpiano Bezerra de Meneses (2002), tornou-se referência na possibilidade de se escrever história com fotografias. Nesse artigo, com um propósito puramente metodológico (MENESES, 2002, p. 133), Meneses convoca o leitor a avaliar a possiblidade de análise histórica de uma única fotografia. A famosa fotografia de Robert Capa passa pelo escrutínio da análise morfológica, das controvérsias em torno de sua autenticidade, dos motivos pelos quais se deu o processo de iconização da fotografia associado à sua notoriedade pública e aos elementos visuais que Ihe atribuíram um valor único. Finalmente, a fotografia ganharia uma biografia (não autorizada), em que o autor se vê compelido a examinar outras fontes que não a imagem, agregando valor cognitivo àquilo que a imagem apresenta. 
Os percursos da análise de Meneses para a fotografia de Capa se assemelham aos círculos hermenêuticos em torno dos quais os significados dos textos agregariam sentido ao documento original. Entretanto, o fundamental da análise reside em considerar a materialidade da fotografia e em reunir um conjunto de informações que permitam estudar a foto nas diversas formas e situações de uso e apropriação: “É imperioso, portanto, passar das camadas rarefeitas e genéricas para patamares específicos e diferenciados da História. O melhor caminho para tanto, praticamente, é materializar o documento, considerá-lo também como um objeto material e não só como um abstrato emissor semiótico" (MENESES, 2002, p. 144). Na conclusão de seu artigo, Meneses não nos deixa esquecer:

Não são, pois, documentos os objetos da pesquisa, mas instrumentos dela: o objeto é sempre a sociedade. Por isto, não há como dispensar, aqui, também a formulação de problemas históricos, para serem encaminhados e resolvidos por intermédio de fontes visuais, associadas a quaisquer fontes pertinentes. Assim, a expressão "história visual" só teria algum sentido se se tratasse não de uma História produzida a partir de documentos visuais (exclusiva ou predominantemente), mas de qualquer tipo de documento e objetivando examinar a dimensão visual da sociedade. 'Visual' se refere, nestas condições à sociedade e não às fontes para seu conhecimento [...] Como implicado na proposta de estudo da imagem como objeto, trata-se de analisar a cultura visual, os regimes visuais, as instituições visuais, os ambientes visuais estruturados pelos fatores socioculturais), em uma palavra, a visualidade. (MENESES, 2002, p. 150-151)

A proposta de Meneses ganhou uma versão mais recente no trabalho das historiadoras Solange Lima e Vania Carneiro (2018), sobre a fotografia feita por Nilüfer Demir, do corpo menino sírio, Aylan Kurdi, encontrado morto na praia da turística Turquia, depois de afogar-se no Mar Egeu, durante a tentativa de fugir da guerra civil na Síria, em setembro de 2015.

O ponto de partida das autoras foi justamente a comoção mundial causada pela fotografia do corpo do menino. O estudo de caso procura responder a uma pergunta: por que essa e não outras imagens de crianças em situações muito semelhantes, a mais próxima sendo a de seu irmão Galeb, morto da mesma forma e na mesma praia, tornouse símbolo da tragédia que se abateu sobre aqueles que, entre 2015 e 2016, deslocaram-se 
poder de agenciamento e os novos caminhos da circulação que hoje as imagens possuem graças às redes sociais digitais. Trata-se, portanto, de um estudo que se volta para a potência da imagem na cultura contemporânea, sobretudo, em face ao desafio colocado pelas novas economias visuais das redes digitais à fotografia pública nesse ambiente.

Em âmbito internacional, Hariman e Lucaites por meio da publicação do livro No Caption Needed (2007) contribuíram para a consolidação da noção de foto-ícone na análise das imagens emblemáticas do fotojornalismo do século XX. Para a dupla de autores, os foto-ícones são importantes artefatos da cultura pública por mobilizarem ao seu redor diferentes posições políticas e aglutinarem expectativas em torno de determinadas situações ou eventos históricos. Definem foto-ícones como imagens que circulam na imprensa, em mídias eletrônica e digital que são amplamente reconhecidas e lembradas; são compreendidas por representarem eventos historicamente significativos, por ativarem respostas ou identificação fortemente emocionais, e são reproduzidas por meio de um conjunto variado de veículos. Nem sempre são imagens premiadas, algumas vezes circulam em comunidades mais estritas e outras tantas podem adquirir uma extensão universal. Entretanto, uma característica os autores confirmam, os foto-ícones foram capazes de disseminar cidadania, meios de viver modernamente a política, de se adquirir direitos iguais, obrigações coletivas e de criarem princípios comuns para a identidade pública. Seriam ícones da cultura pública liberal-democrática(HARIMAN \&LUCAITES, 2007, p. 28).

A associação automática dos foto-ícones à condição política da democracia liberal e capitalista pode ser redutora para análises que compreendem outras experiências históricas, do mesmo modo que, a sua positivação como expressão de uma cidadania visual indiscutível reduz a capacidade heurística da noção. De fato, há que se ponderar o valor histórico de uma única imagem tanto em correspondência com o universo visual no qual se inscreve, quanto na forma como incorpora as múltiplas temporalidades da história. Uma perspectiva alternativa à associação automática do foto-ícone à cultura 
visual da democracia liberal, deve avançar no caminho aberto pelos estudos sobre cultura visual de procedências variadas (KNAUSS, 2006, 2008) e propor uma história com imagens em que se tome as cautelas necessárias já notificadas por Meneses, quais sejam, se olha a imagem, mas se mira a sociedade que a produziu e consumiu.

O panorama esboçado em torno das questões que orientam o estudo da imagem pública na atualidade objetivou as principais posições e tendências no debate atual. Entretanto, há que se tomar um caminho que opere tanto dimensão social da experiência visual quanto dimensão visual de toda a experiência social (MITCHELL, 2005, p. 255). Um caminho que tenha como corolário ético e político a necessidade de se considerar as diferentes posições em jogo na História e o seu compromisso com o pensamento crítico. Dessa maneira, a análise apoiada em uma série visual ou voltada para um foto-ícone, partirá sempre de uma pergunta que se lança para a imagem. Na sequência do texto, indica-se uma linha de abordagem que toma a imagem fotográfica, sua circulação no espaço público visual e seu potencial de condensar a experiência histórica como um possível caminho.

\section{Por uma história fotográfica}

Em uma coletânea de ensaios intitulada "O ornamento da massa", o teórico alemão Siegfried Kracauer (2009), reuniu um conjunto de artigos publicados ao longo das décadas de 1920-30, quando ainda vivia na Alemanha e compartilhava do mesmo ambiente intelectual de Walter Benjamin, Theodore Adorno, e demais integrantes da reconhecida Escola de Frankfurt. A compilação de ensaios dos anos 1920 e 1930, publicada em 1963, originalmente em alemão e com tradução no mesmo ano para o inglês, incluiu um ensaio intitulado Fotografia que, no entanto, difere de um outro texto, com o mesmo título, escrito em 1927, que foi publicado no prestigioso periódico alemão, Frankfurter Zeintung.

Kracauer inicia o texto de 1927, com uma imagem, a fotografia de uma "Diva do cinema" - "Ela está na capa de uma revista ilustrada, diante do hotel Excelsior no Lido." 


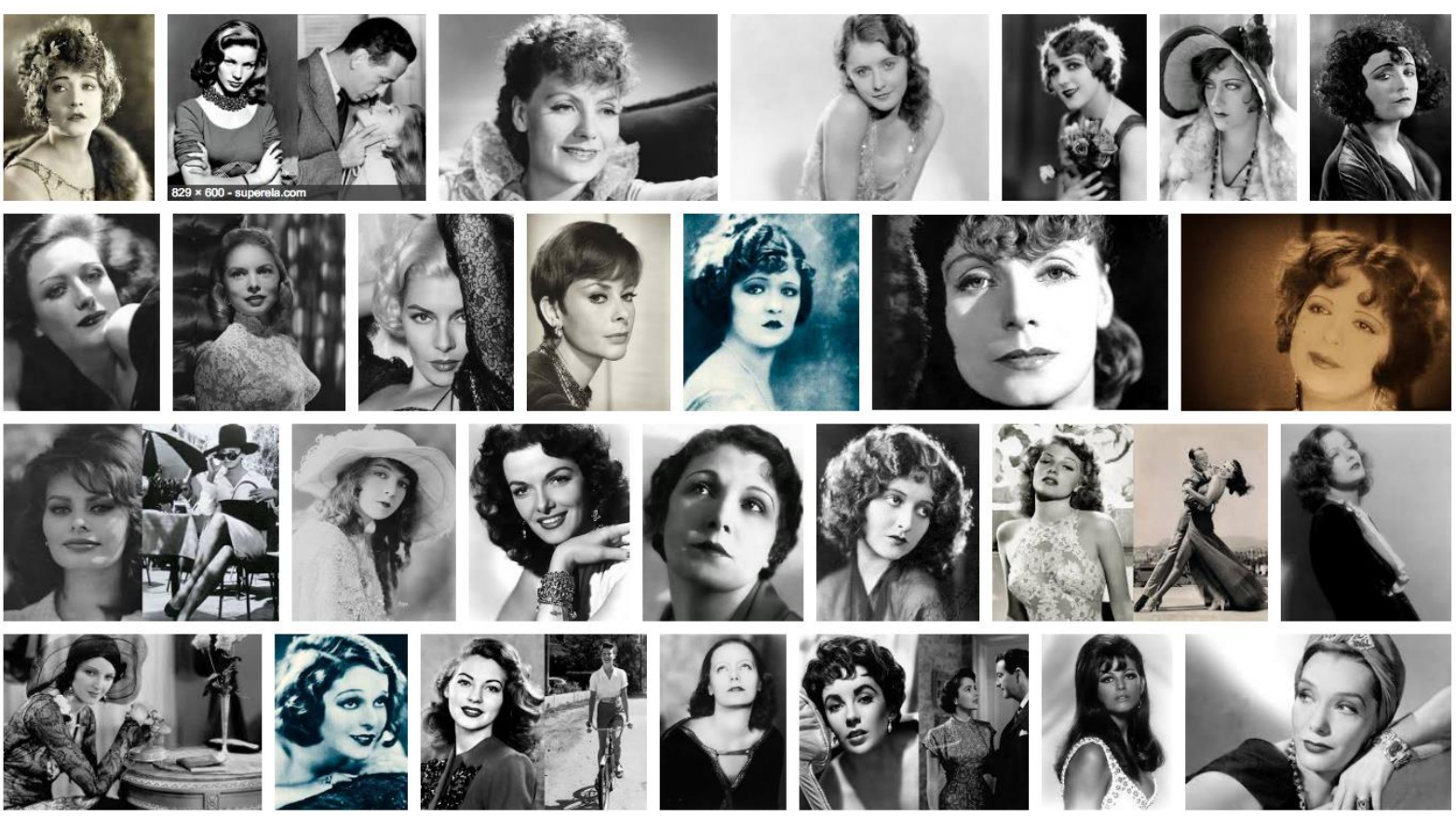

Fig. 2: Um mosaico composto pelo Google Imagens na busca por "divas do cinema”. Acesso em: 14/12/2017.

"Estamos em setembro. Se alguém olhasse através de uma lupa. Veria, na retícula, os milhões de minúsculos grãos, a diva, as ondas e o hotel. Certamente a imagem não pretende mostrar uma retícula de grãos, mas a diva de carne e osso. A reportagem a chama de demoníaca; nossa diva demoníaca" (KRACAUER, 2009, p. 62). Nessa referência, Kracauer já deixa claro o seu ponto de partida - a crítica do realismo como a base do conhecimento e a necessidade de tomá-lo como uma forma de pensar o mundo - um sistema de codificação.

Ao se debruçar sobre a fotografia, Kracauer mira a História e as formas de subjetivação das experiências com o tempo - duração, extensão, diferença e ruptura. Ao caracterizar a fotografia como um contínuo espacial, reconhece a sua capacidade de encapsular o tempo. O tempo encapsulado é também o tempo da memória, diferenciada pelo autor, por duas dimensões. Uma lacunar, fragmentária e subjetiva: “A memória não se ocupa de datas, pula sobre os anos ou dilata a distância temporal. [...] A seleção foi feita desta e não de outra maneira, pois as disposições e as intenções exigem o recalque, a falsificação e a alteração de valores do objeto [...]. Não importa quais cenas um indivíduo recorda: elas querem dizer algo que se relaciona a ele sem ele precisar saber o 
que elas querem dizer. Elas são conservadas justamente em relação ao que querem lhe dizer" (KRACAUER, 2009, p. 67). A outra dimensão, é essencial, compacta e reveladora. 0 seu reconhecimento pela consciência liberta coloca o sujeito em face à sua própria história, ao se compreender como sujeito temporal: "a última imagem de um indivíduo é a sua própria história" (KRACAUER, 2009, p. 67).

A princípio, a variedade de imagens que povoam os semanários ilustrados que circulavam nos anos 1920, provoca no autor uma reação de rejeição e conflito, que o leva a denunciar enfaticamente a produção em massa de imagens e o "rosto fotográfico" que “o mundo assumiria” (KRACAUER, 2009, p. 67). Observa-se nessa denúncia, aspectos do argumento que servirá de base para a conversão crítica da fotografia moderna: a fotografia como um arquivo universal de imagens-síntese. A profusão de fotografias subordinadas ao processo de produção capitalista baniu, definitivamente, da imagemmemória a sua dimensão subjetiva, e passou a engendrar simulacros de experiência que levariam à perda do valor do conhecimento, proporcionado pelas imagens, e a valorização do efêmero das celebridades. A eternização de um presente contínuo nas fotografias modernas, não mais ameaçado pela iminência da morte, transformou a imagem-memória em imagem-arquivo.

Os próprios contornos dessa sociedade aparecem eternizados como despojos de uma civilização passada, pelas fotografias nas revistas ilustradas, oferecendo-se à consciência emancipada a chance de produzir uma crítica a partir de seus próprios termos, e experimentar sobre elas o seu próprio poder: "A guinada em relação à fotografia representa o jogo de azar da história" (KRACAUER, 2009, p. 78). Portanto, apesar de criticar a massificação que a fotografia moderna sofre, sobretudo, por meio de sua veiculação nas revistas ilustradas, Kracauer vê na função arquivo da fotografia, a capacidade de expor o fundamento natural do mundo - para além da memória subjetiva - um mundo que se torna mundo pela imagem fotográfica.

O estreito diálogo de Kracauer com o filósofo alemão Walter Benjamin (2008, p. 115-145), converge para um ponto central, a relação que o sujeito moderno estabelece com o mundo visível pela mediação estética pautada nos princípios de um mundo tecnológico. O que acontece com essa relação, quando a fotografia deixa de ser objeto 
de apreciação e passa a criar um padrão de representação compartilhado por todos os sujeitos e, portanto, naturalizado como a representação por excelência do real imaginado? À arte que se apresenta como sublime se opõe a representação técnica, na qual descansa o olhar e exalta a consciência da visão. De tal modo, indaga sobre a sociedade que se revela nesse novo tipo de configuração visual do social - ou ainda, nesse novo regime de visualidade.

Benjamin elege a fotografia como elemento central na economia visual que se organiza a partir da segunda metade do século XIX, inserida num patamar civilizatório, no qual o capitalismo surge como condição histórica. Daí a perda da aura constituir um problema para a percepção estética que se vê ameaçada pela naturalização da imagem técnica massificada, já identificada por Kracauer no texto de 1927. A perda da trama espaço-temporal - deslocamento e distanciamento - relativa à experiência aurática, acabaria por aprisionar no tempo/espaço as posições de classe que são históricas e, portanto, passíveis de serem transformadas.

A condição histórica que se apresenta na era da reprodutibilidade técnica tem como conceito-chave o progresso - de onde se desdobram noções fundadoras do indivíduo moderno: técnica, velocidade, conforto, movimento, beleza, individualidade tanto para o produtor de imagens quanto para seu receptor, e se define um mesmo universo de signos visuais que orientam a elaboração de linguagens e a sua compreensão. No projeto benjaminiano, para compreender a história calcado na percepção da emergência do moderno regime de visualidade, resultante da crise da representação visual clássica, coloca a fotografia como experiência central por encapsular passado e futuro resultando numa imagem dialética.

Ao se observar o ambiente das publicações ilustradas, percebe-se a conformação de um espaço público visual que, desde finais do século XIX e ao longo do século XX, se associa ao processo de internacionalização da cultura burguesa. Nesse movimento, as revistas ilustradas apresentam-se como plataformas de lançamento de imagens que se espalham no tempo e no espaço da experiência histórica. Resultados de uma moderna prática fotográfica, as imagens nas Ilustradas caracterizam-se por agenciarem múltiplas versões dos acontecimentos e plasmarem memórias históricas. Cabe indagar o que dessa 
prática ainda resiste na experiência contemporânea no espaço público virtual, o que nos leva para as imagens em fuga dos suportes originais para cumprir o seu destino de imagem assumindo novos corpos (BELTING, 2012).

\section{Imagens em fuga}

As leituras de Kracauer e Benjamin podem orientar a análise da fotografia moderna nas llustradas por diferentes percursos. Entretanto, quero enfatizar o aspecto histórico que ambos destacam na fotografia, pois em vários momentos de seu texto, Kracauer associa fotografia à história, como recorte do contínuo espaço-temporal; da mesma forma, Benjamim afirma que não há história que não seja fotográfica, pois a fotografia moderna - marcada pela instantaneidade - permite que passado e futuro se encontrem num agora. Ambos, também, destacam a dimensão de arquivo que potencializa as fotografias como restos de experiências passadas colocados em movimento pelos trabalhos de memória - individual e social (LISSOVSKY, 2014).

Assim, pode-se pensar em uma espécie de trânsito de imagens quando navegamos pela internet no sistema de busca booleana ${ }^{2}$. As imagens em fuga do local onde estariam arquivadas ou dos suportes em que foram veiculadas, causam pânico ao historiador, por incorrer riscos de descontextualização, ou ainda pior, o risco de anacronismo. Entretanto, há que se pensar que a "guinada da fotografia é o jogo de azar da história", como argumenta Kracauer, liberadas de sua função exclusivamente ilustrativa, as fotografias ganhariam vida na produção de um novo conhecimento, autônomo em relação ao passado historicamente delimitado, mas em sintonia com o passado possivelmente representado, o que confere sentido a uma história das representações.

Para que esse argumento não caia no vazio, apresento dois breves estudos de caso: o primeiro, relativo ao século $\mathrm{XX}$, em que convoco novamente as imagens do presidente Getúlio Vargas, desta vez, organizadas por meio de uma narrativa visual; o segundo, relaciona-se às metamorfoses da imagem pública de Oprah Winfrey, na entrega do Globo de Ouro, em janeiro de 2018 e o seu destino político ao lado de Barack Obama.

\footnotetext{
${ }^{2}$ Em linhas gerais, os sistemas de busca booleanas são as buscas avançadas, que reúnem uma ou mais palavras-chave por meio de conectivos.
} 


\section{A volta ao retrato do Velho}

A sequência de imagens publicadas na gaúcha Revista $O$ Globo, de autoria do fotógrafo Flávio Damm, integrou a fotorreportagem intitulada “A Longa Viagem de Volta", em 1948.
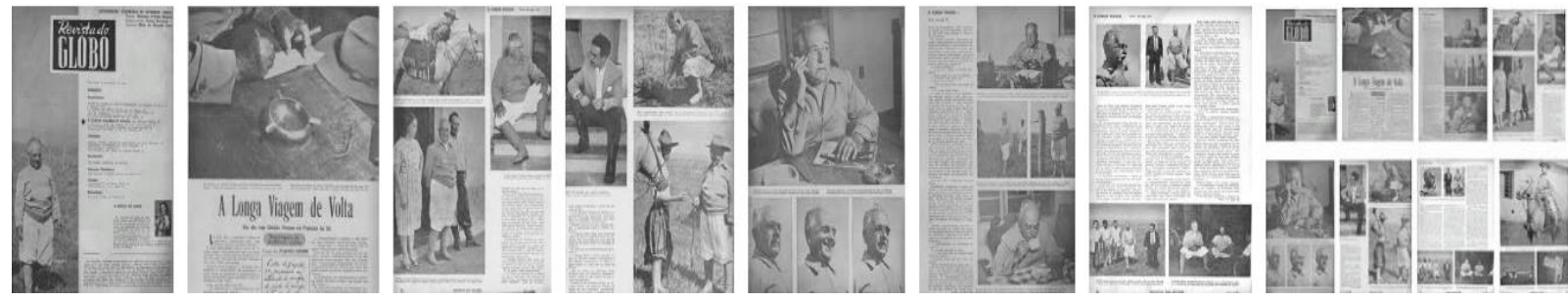

Fig. 3: "A longa iagem de Volta", fotorreportagem publicada na Revista do Globo, em 6 de novembro de 1948.

Em 1949, o então jovem fotógrafo gaúcho Flávio Damm, ganharia o seu salvoconduto para a capital federal e um lugar na renomada revista carioca O Cruzeiro, com publicação na gaúcha Revista do Globo, das primeiras fotos de Getúlio Vargas, no exílio, na sua fazenda de Itu, depois de deposto em 1945. A estratégia de 'reaparição' de Getúlio Vargas no espaço público visual foi articulada por políticos, entre os quais, João Goulart, que reconheciam as chances do ex-presidente em voltar à cena política pela via eleitoral no pleito de 1950.

Da seleção resultante da pesquisa em acervos virtuais na internet, com a palavrachave - Getúlio Vargas, emerge um presidente que circula no espaço público visual em plena performance do exercício do poder. Dessa atuação, destacam-se algumas características: gestuais - o abraço, o sorriso, o aceno ao público; de indumentária uniforme, ternos claros, ternos escuros, gravatas, fraque, cartola, chapéu; de ambientes: gabinetes, estádios, praças, ruas; eventos: reuniões, comícios, paradas cívicas. O presidente apresenta-se no centro da fotografia em interação com uma grande variedade de atores sociais - dignitários de países estrangeiros, militares, população, índios - que gravitam em torno de uma espécie de planeta presidencial.

Demarcam-se, por meio dessa performance, elementos de uma cultura política forjada em torno da figura do presidente detentor do poder de dinamizar a imagem com seus gestos, movimentos e interações. $\mathrm{O}$ acesso a essas imagens pelos consumidores dos 
veículos da imprensa ilustrada, tornados espectadores da performance presidencial, os orienta a se inserir no espaço visual comum e compartilhar dos signos que os identificam como participantes de uma mesma comunidade imaginada: o Brasil.

Já a fotorreportagem de 1949, produzida em um momento crítico da trajetória política de Getúlio Vargas, se caracteriza pela marca da encenação da pose fotográfica. Flávio Damm apoia a sua prática fotográfica nos cânones da moderna fotorreportagem (COSTA, 1993). Suas fotografias produziram uma narrativa em que o político, mais uma vez, protagonizava uma intriga. Detalhes dos gestos, poses programadas, cenografia composta com os próprios objetos pessoais do presidente: a caneta, o charuto, a xícara, garantiram ao espectador acesso à intimidade do político compartilhando com ele suas expectativas em relação ao retorno à vida pública e aos anseios de assumir novamente a presidência.

Nesse registro, Getúlio Vargas se aproxima da diva do cinema com que Kracauer (2009) iniciou seu texto sobre fotografia de 1927. A diva sobreviverá nas páginas das revistas ilustradas com toda a sua "beleza demoníaca", alimentando a imaginação dos fãs do cinema nos anos 1920. As tramas e intrigas políticas que envolveram o retorno de Getúlio Vargas à cena pública e alimentaram a cultura política dos anos 1940 e 50, permanecem acessíveis nas imagens-arquivos depositadas nas revistas ilustradas.
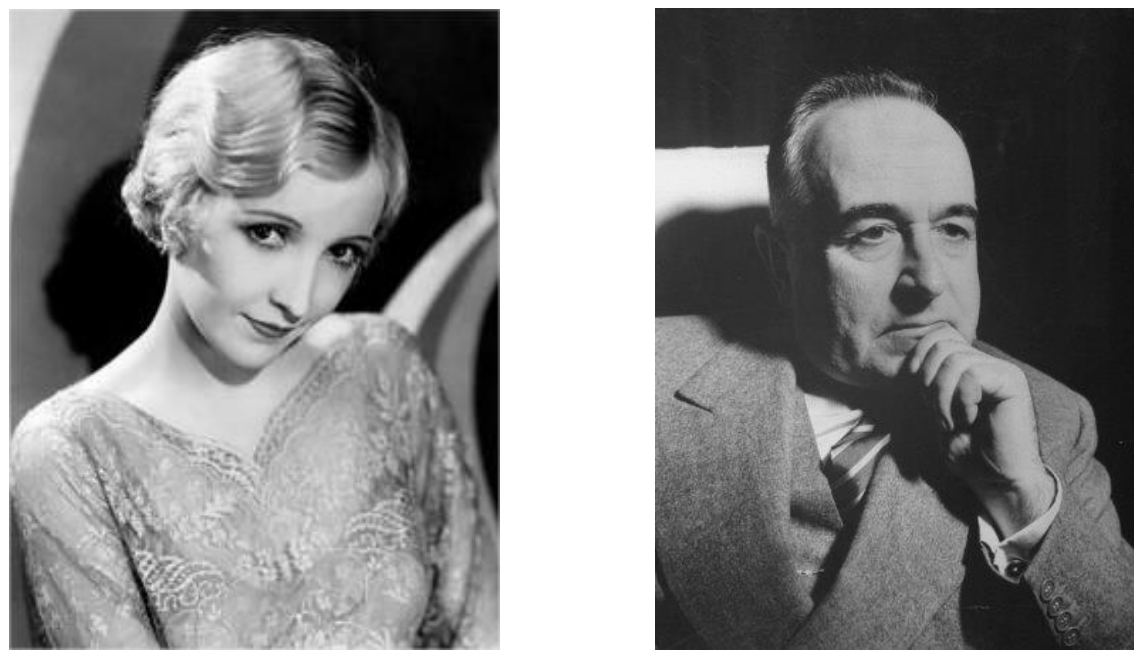

Fig. 4: Mary Pickford, uma das divas do cinema dos anos 1930, e Getúlio Vargas em retrato oficial.

A diva e o presidente referem-se às dimensões possíveis do espaço público visual que se constituiu ao longo do século XX na imprensa ilustrada. Sem esquecer que, como 
“imagens em fuga”, fazem parte de um regime historiográfico em que as imagens valem mais como representação do que como prova.

\section{Outra diva e outro presidente, um exemplo no século XXI}

Nos dias que se sucederam à cerimônia de entrega do Globo de Ouro, de janeiro de 2018, famosa premiação concedida aos artistas do star system dos Estados Unidos, as páginas dos jornais impressos e as redes sociais transformaram em notícia o discurso de agradecimento da apresentadora e uma das mais importantes celebridades negras da atualidade: Oprah Winfrey. Atualmente com 63 anos, Oprah foi apresentadora de um programa de televisão por 25 anos, em que arregimentou fãs seguidores no mundo todo, tornando-se a primeira afro-americana bilionária no país.

Ao longo de sua carreira, a apresentadora se destacou pela defesa dos direitos civis da população negra dos Estados Unidos, com reconhecimento por partes do movimento negro. Depois de encerrar o seu programa vespertino, em 2011, Oprah foi agraciada com a Medalha da Liberdade, a mais alta honraria concedida a civis no país, e o vestido que usou no último show merece destaque na exposição do Museu de História e Cultura Afro-americana, o Freelon Adjaye Bond, localizado em Washington D.C. Em seu discurso, na noite de domingo, 7 de janeiro de 2018, Oprah colocou em ação todos os elementos para compor a sua épica de herói mulher e negra, em um mundo segregado onde combateu para vencer os desafios que sua jornada lhe impôs e se colocar como um modelo: "Eu quero dizer a todas as meninas que estão assistindo aqui, agora, que saibam que nasce um novo dia no horizonte" (Folha de São Paulo, terça-feira, 7/1/2018, caderno Mundo, A9).

Os heróis na concepção clássica do termo atuam como imagens modelares, como símbolos que incorporam valores que superam a condição humana. Assim foi com Ulisses, dos contos Homéricos, assim foi com Artur da gesta dos cavaleiros medievais, e assim poderá ser com Oprah, que encanaria a esperança de um novo dia no horizonte do mundo globalizado das redes sociais, tornando-se uma imagem símbolo no 'olimpo' das celebridades. Nesse registro, rapidamente, sua imagem se metamorfoseou de celebridade bilionária para potencial candidata à presidência dos Estados Unidos, em 2020. Uma candidata capaz de jogar na oposição no campo das celebridades, em que se 
situaria o atual mandatário do país, afinal, ambos ganharam notoriedade em programas de televisão e se tornaram bilionários, em que pese as notórias diferenças entre os dois.

Não se propõe aqui uma análise da conjuntura política dos Estados Unidos, mas os efeitos da metamorfose da imagem pública de Oprah Winfrey, e sua reverberação no espaço público visual da atualidade. Mais uma vez, sem pretender esgotar os circuitos sociais por onde a imagem navegou e os itinerários que prescreveu num campo em disputa, a análise se concentra na criação do foto-ícone e seu valor político. O ponto de partida foi o discurso feito na cerimônia de entrega do Globo de Ouro, com cerca de 8 minutos que se espalhou nas redes sociais, em versões editadas; o desdobramento nos canais da grande imprensa identificou o discurso de agradecimento a um potencial lançamento da apresentadora à Casa Branca. Paralelamente, nas redes sociais, pipocavam críticas sobre o compromisso de Oprah com o establishment de Hollywood. Quando o discurso chega às mirradas folhas dos jornais impressos, encontra-se sintetizado em torno do ponto de impacto do evento - Oprah Winfrey para presidente em 2020, a imagem icônica nasce dessa ideia. ${ }^{3}$

No discurso da noite do dia 7 de janeiro, Oprah se refere a ela como uma 'little girl' que em 1964, assiste a entrega de um Oscar, o mais prestigioso prêmio da Academia de Cinema de Hollywood, a um ator negro: Sidnei Poitier. A surpresa da pequena Oprah, ao ver pela primeira vez um homem negro tão bem-vestido, estabelece uma relação com as demais pequenas Oprahs que a estariam assistindo naquele momento, garantindo pela ênfase dada à frase: "a new day on the horizon". Em outros momentos, como na referência a Pecy Taylor, mulher negra estuprada aos 24 anos por seis homens brancos em 3 de setembro de 1944, e que se tornaria um dos símbolos da luta pela igualdade de justiça entre negros e brancos nos Estados Unidos. Entretanto, Oprah não limita o endereçamento de seu discurso às mulheres afro-americanas, incorpora-as no movimento contra o assédio sexual em Hollywood, simbolizado pelo movimento \#MeToo, mas também outras mulheres anônimas, trabalhadores das cidades e do campo, e ainda os homens de valor que apoiam uma sociedade justa e não segregada.

\footnotetext{
${ }^{3}$ O discurso de Oprah Winfrey do dia 7 de janeiro de 2018, pode ser assistido com legenda em português, disponível em: <www.youtube.com/watch?v=nlOVquKPUMU> e $<w w w . y o u t u b e . c o m / w a t c h ? v=q r J l u l F x b M w>$. Acesso em: 31/01/2018.
} 
Da mesma forma que em seus programas vespertinos, Oprah fala para a sua comunidade de sentido, mas cria um novo destino para as suas palavras - uma América imaginada em torno do ideal constitucional de 1780: "Pursuit of happiness" - a busca da felicidade. Entretanto, em uma sociedade forjada pela ética protestante, esse princípio não teria nada de hedonista, significaria devotar a vida ao trabalho e às atividades que resultassem em benefícios para toda a comunidade. O que garantiria acesso a bens materiais, sem abdicar da espiritualidade e dos valores morais consagrados pela coletividade. A imagem de um novo dia no horizonte, enfatizada por Oprah em seu discurso, sintoniza-se a esse princípio. Ela, como enunciatária que se apoia em uma trajetória bem-sucedida, seria a fiadora de um novo tempo de felicidade, que tomou a forma da sua candidatura à Casa Branca.

Entretanto, vozes dissonantes, como a do cantor inglês Seal, que em depoimento em sua página no Facebook, denuncia a hipocrisia de Hollywood, em não tratar dos reais problemas do racismo e edulcorar ações politicamente relevantes, como as denúncias em torno do produtor Harvey Weinstein por assédio sexual. Destacando-se no depoimento as estreitas relações da entrevistadora com o produtor.
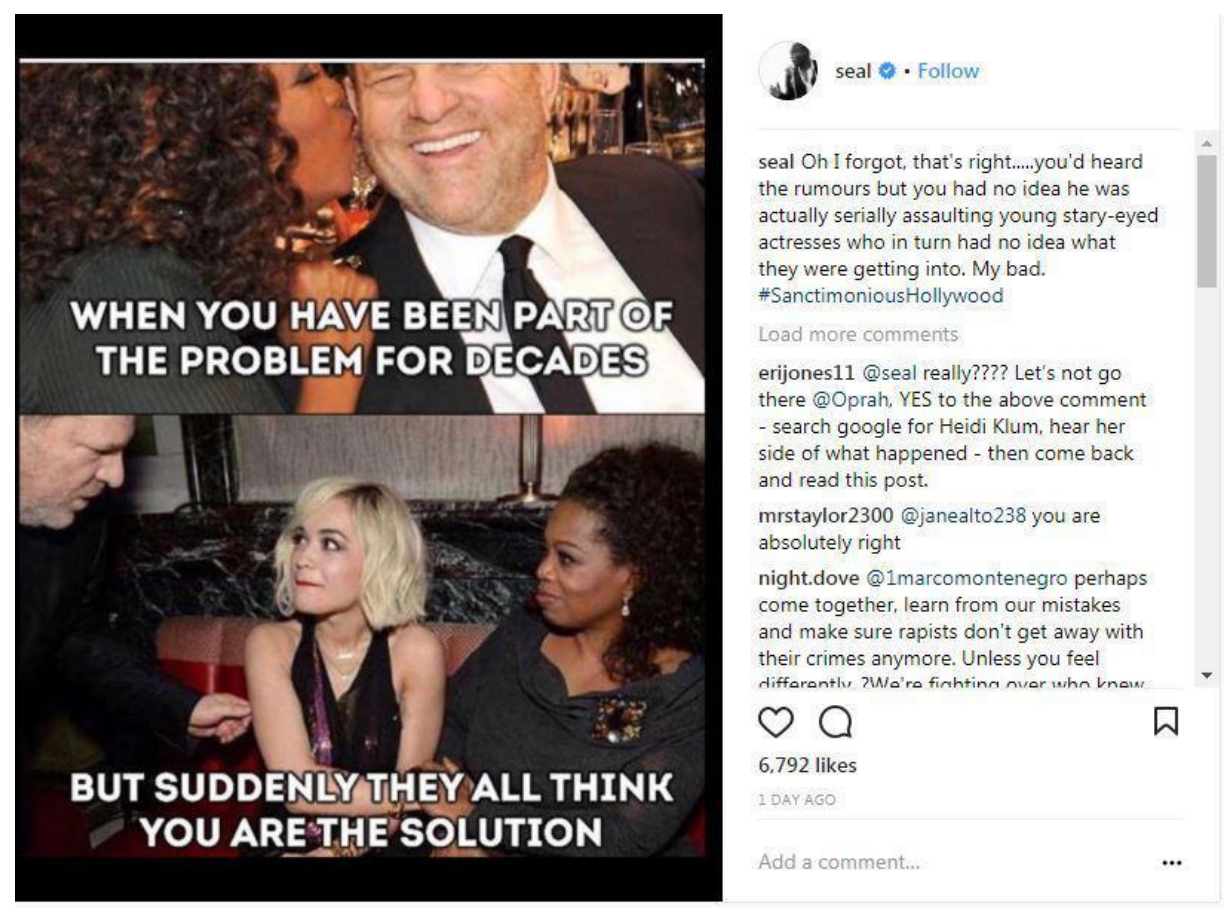

Fig. 5: Post do cantor Seal na sua página no Facebook, que se espalhou pela internet. Disponível em: $<$ http://blitz.sapo.pt/principal/update/2018-01-13-O-post-de-Instagram-do-cantor-Seal-que-Oprah-Winfreyainda-nao-comentou>. Acesso em: 23/01/2018. 
As denúncias e críticas, no entanto, não repercutiram no mesmo diapasão que o discurso da artista. O que se acompanha nas redes sociais e páginas dos grandes veículos da mídia ocidental é a metamorfose da imagem pública de Oprah Winfrey. A página do jornal a Folha de São Paulo, no dia 09/01/2018, apresenta a síntese de uma metamorfose que levou dois dias para ser engendrada.

\section{FOLHA DE S.PAULO}

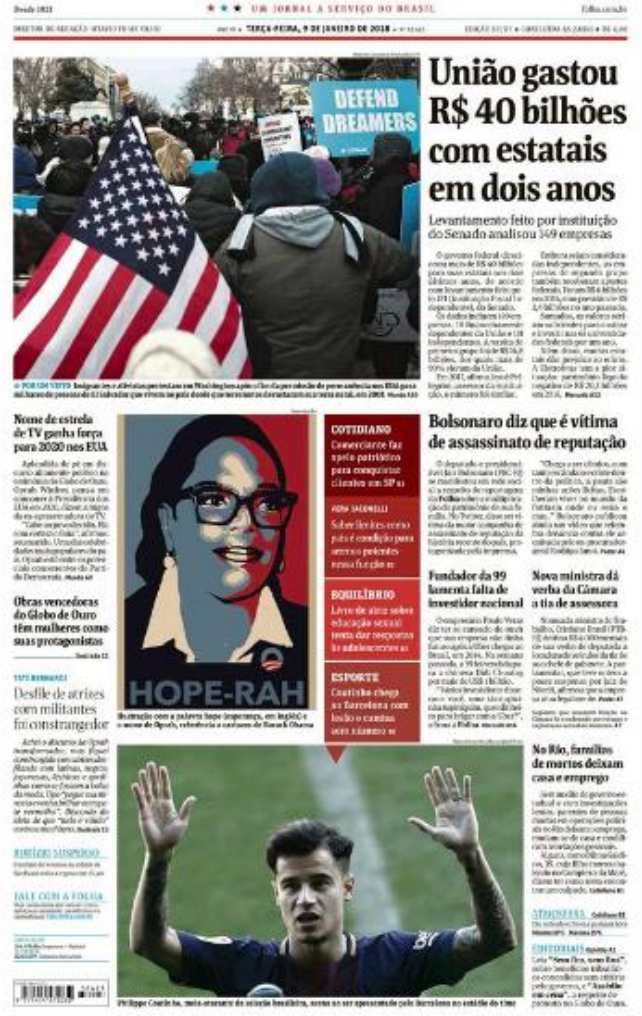

Fig. 6: Primeira página da Folha de São Paulo. São Paulo, 09/01/2018.

A composição gráfica dessa primeira página é sugestiva, pois alinha três imagens associadas ao princípio contemporâneo de "busca da felicidade". No alto, em tamanho grande, a foto do protesto em Washington DC, de autoria de Andrew Caballero-Reynolds (AFP), apresenta em primeiríssimo plano a bandeira dos Estados Unidos. Com os manifestantes de costas, não se mostram rostos, mas o cartaz que se destaca em azul, no canto direito, os identifica com sua comunidade de sentido: "defend dreamers" ou "defenda os sonhadores”. A frase refere-se a última geração de imigrantes que apostou no "sonho americano", como complementa a legenda da foto: "Por um visto. Imigrantes e ativistas protestam em Washington após o fim da permissão de permanência nos EUA 
para milhares de pessoas de El Salvador que vivem no país desde que terremotos devastaram a sua terra natal, em 2001". Logo abaixo, insere-se a imagem de Oprah Winfrey acompanhada da legenda: "Ilustração com a palavra hope (esperança, em inglês) e o nome de Oprah, referência a cartazes de Barack Obama". Mais adiante, essa relação será mais bem trabalhada, mas, para garantir a coesão do sentido que se produz nessa primeira página, basta indicar que o presidente Obama, apesar de não ter rompido com a cartilha neoliberal e de avançar muito pouco nas questões de imigração, saiu da Casa Branca com aprovação em torno de $60 \%$ da população. Uma nação feliz com seu presidente. Por fim, mas não menos importante, na foto do jogador brasileiro, Philippe Coutinho, meia-atacante da seleção brasileira de futebol, acena ao ser apresentado pelo Barcelona, no estádio do time. Jogadores de futebol, em um país como o Brasil, marcado pelo aprofundamento da desigualdade social e perda significativa de direitos nos últimos dois anos, incorporam o último bastião da busca da felicidade.

A reportagem em torno do evento do Globo de Ouro, na Folha de São Paulo do dia 9 de janeiro de 2018, ocuparia ainda as páginas da seção Mundo e do caderno llustrada. Em ambas as entradas, a fotografia de Oprah se caracteriza pelo corte da cintura para cima, concentrando-se no movimento das mãos e do rosto, congelando partes de seu discurso. Ela não posa como as demais artistas no tapete vermelho, e se destaca dos “outros possíveis candidatos”. Em uma foto, ela sorri; na outra, lança um olhar direto para a plateia; em ambas, o movimento das mãos fornece dinamismo à imagem.
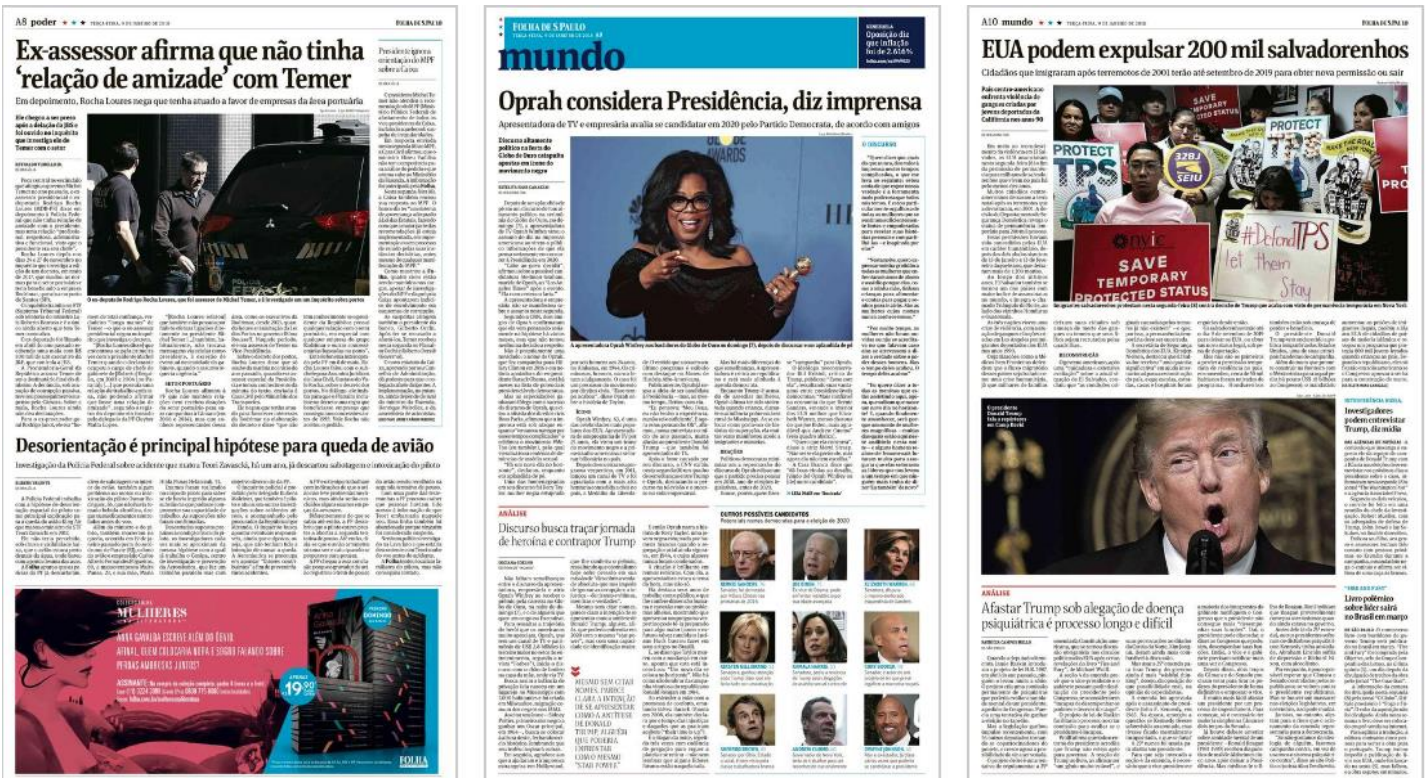


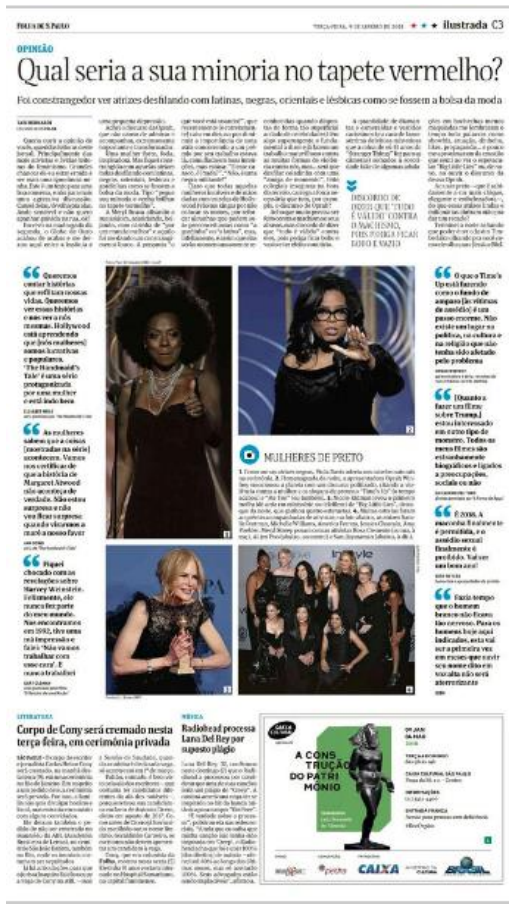

Fig. 7 e 8: Folha de São Paulo, "Mundo", e "llustrada". São Paulo, 09/01/2018.

A ilustração da primeira página não reaparece, entretanto, em torno dela, circulam as demais imagens da edição. Alguns aspectos dessa imagem merecem ser observados de forma mais detida: suas características morfológicas, o sentido político a que se adere e o seu destino como imagem icônica.

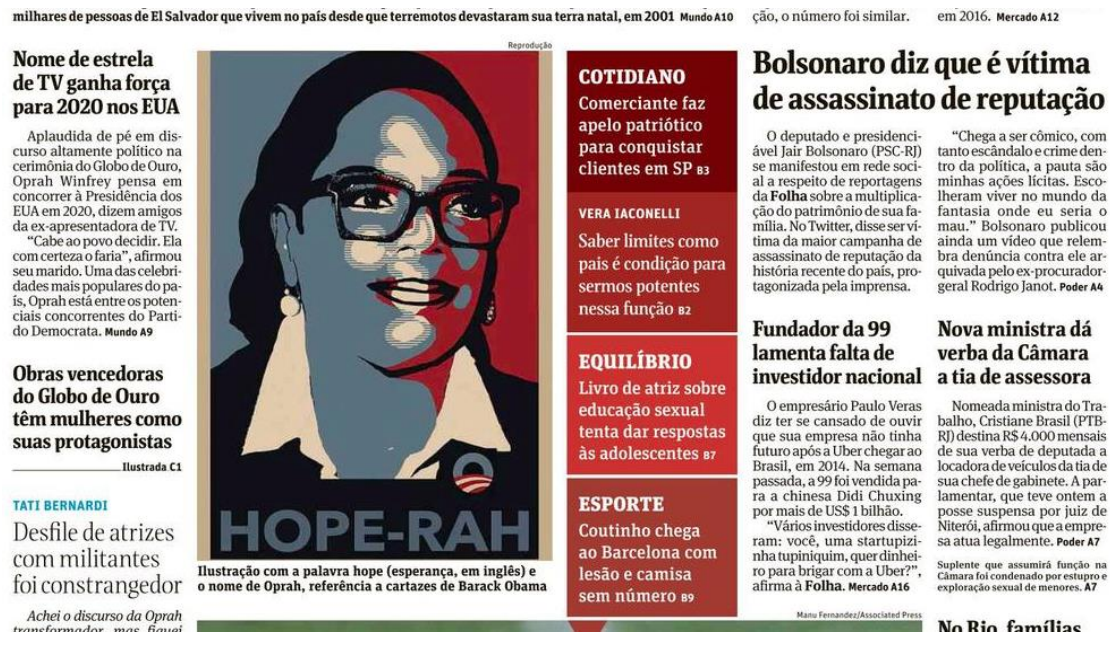

Fig. 9: Detalhe da $1^{a}$ página, Folha de São Paulo. São Paulo, 09/01/2018. 
Do ponto de vista morfológico, trata-se de uma figura produzida com base em um tipo de fotografia, o retrato. Entretanto, não se trata de um retrato de identificação, mas de um retrato de personalidade; seu rosto volta-se levemente para a direita e não mira diretamente o observador. As cores trabalhadas, em torno das cores da bandeira dos EUA, ganham contornos evidenciados pelos efeitos de 'solarização', que ressalta as partes brancas como se estivessem iluminadas, talvez pela luz do dia que nasce no horizonte. Uma outra característica dessa figura é a relação imagem e legenda/slogan, sintetizada em uma palavra de ordem, própria de um tipo de suporte - os pôsteres. 0 recurso foi utilizado para produzir a imagem-ícone do presidente Obama.

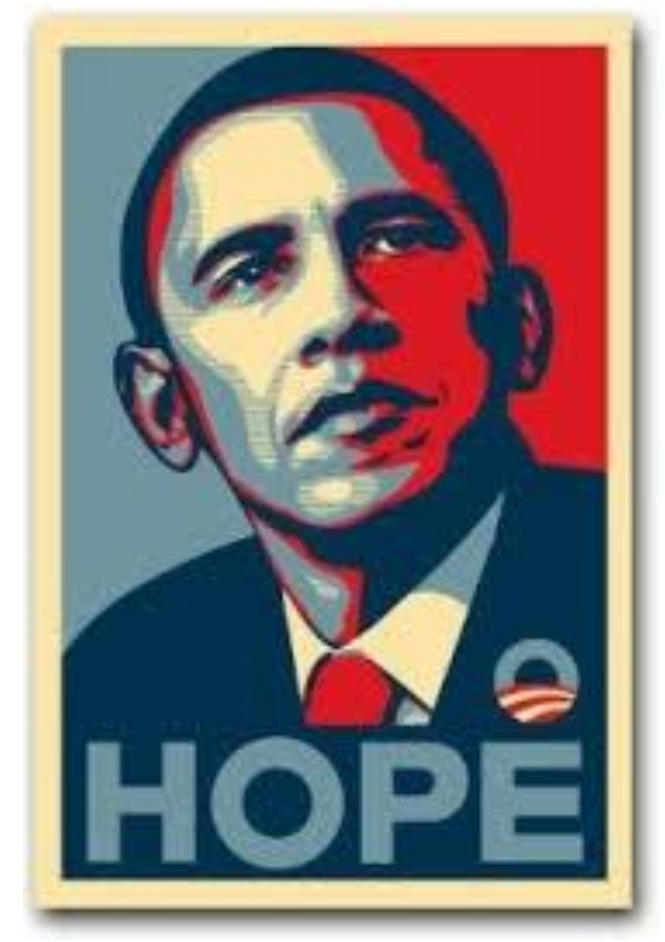

Fig. 10: Cartaz de Barack Obama para a campanha presidencial vitoriosa em 2008. Disponível em: <https://obeygiant.com>. Acesso em: 23/01/2018.

Essa composição foi criada pelo artista e ativista Shepard Fairey, nascido em Charleston, no estado da Carolina do Sul, em 1970. Ele é reconhecido, atualmente, como importante referência na arte urbana. Na página de abertura de seu site, anuncia que, desde 1989, vem produzindo dissidência de qualidade. Uma linha que o associa à ruptura de padrões da arte de galerias e espaços elitizados, em sintonia com o pop e com a arte pública dos grafites. Ocupar a cidade com arte dissidente. 


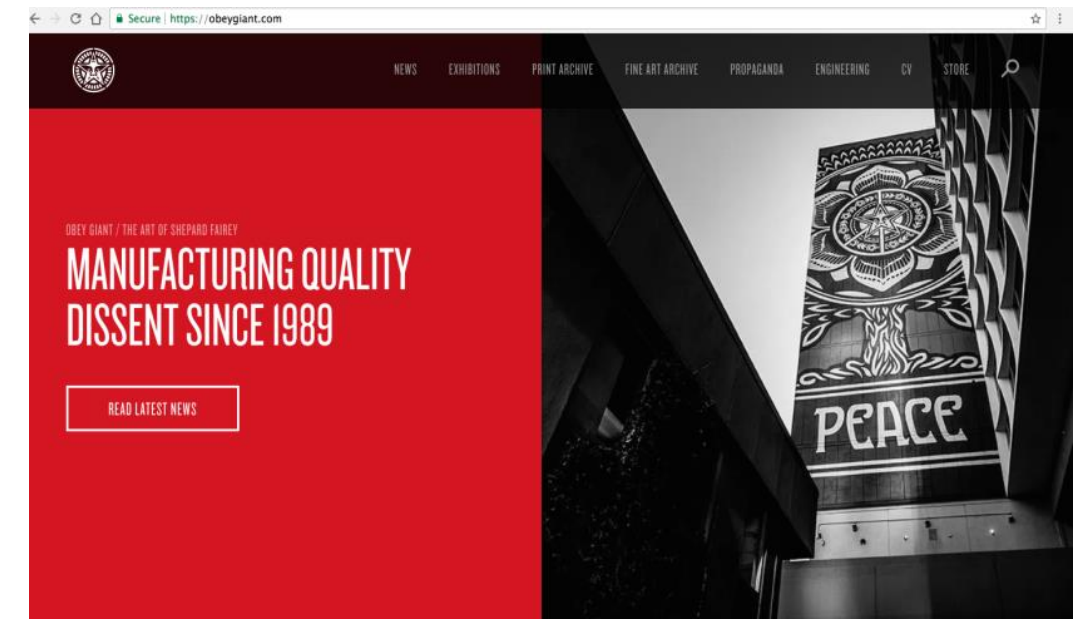

Fig. 11: Página de abertura do site de Shepard Farley, autor da imagem de Obama. Acesso em: 23/01/2018.

Entretanto, ao se lançar esse pôster na história das imagens políticas, encontra-se um outro tipo de alinhamento.

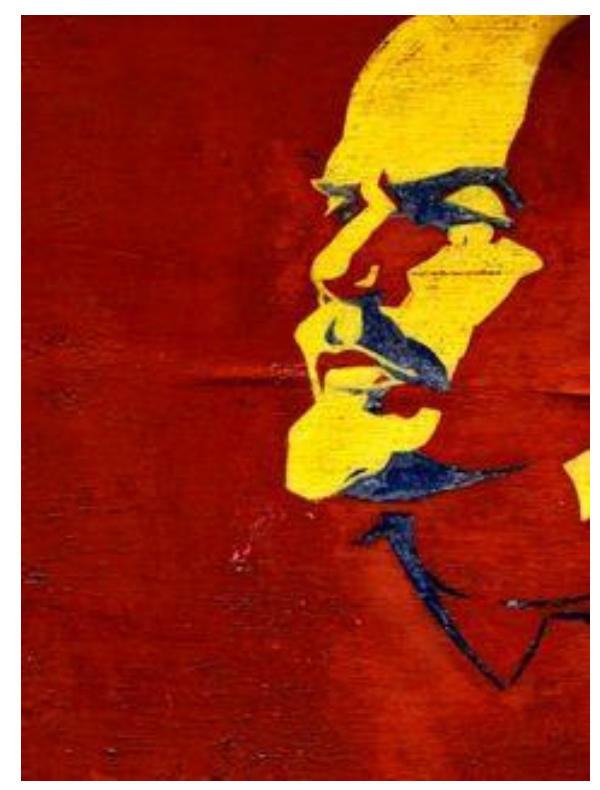

Fig. 12: Pôster Lenin, disponível em: Pinterest <https://br.pinterest.com/pin/109353097171913668/>. Acesso em: 24/01/2018.

A revolução soviética foi exemplar na produção de ícones políticos, em que imagens migravam de fotografias e filmes para bustos em praças públicas e pôsteres. Na imagem de Lenin, líder bolchevique, a cor vermelha predomina e seu rosto se ilumina por 
um amarelo forte, mas que alude à mesma luz que emerge em um outro novo horizonte. A relação formal entre as imagens de Oprah, Obama e Lenin não garante o mesmo alinhamento político, embora se observe que em todos os casos produz-se uma imagem pública que adere aos mundos da 'grande política' capaz de emocionar as massas.

Assim, o sentido político que a imagem de Oprah Winfrey assume, a coloca em linha de sucessão à Casa Branca, na linhagem de Barack Obama, ambos provenientes da comunidade afro-americana que confirmaram a real possibilidade da 'busca da felicidade', tornando-se cada qual a sua maneira e, em seu meio profissional, uma celebridade. Esse alinhamento político a tiraria do universo de celebridades ao qual o atual presidente Donald Trump - estaria associado, deslocando-a do nicho televisivo e do script de apresentadora, para o mundo da política, em que a jornada garantiria o cumprimento do seu destino: trazer a felicidade e afiançar o novo dia.

Cabe, finalmente, observar o destino da imagem de Oprah Winfrey. Quando se opera uma busca no Google images, sobre a imagem icônica da apresentadora, somos enviados para um site em que se vendem camisetas com motivos políticos. Ela encontra a imagem o seu destino, previsto por Kracauer, no mencionado texto de 1929: empacotar o mundo em mercadoria.
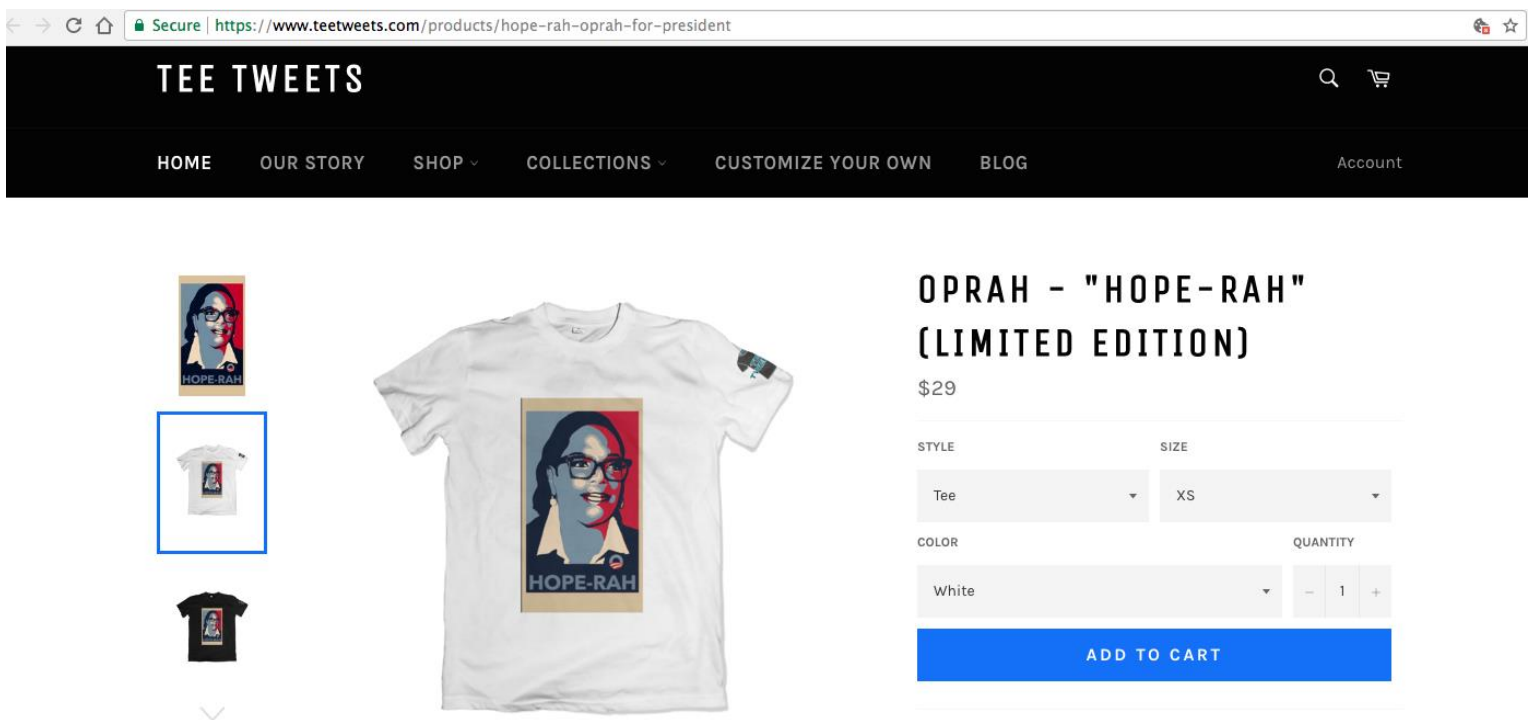

Fig.13: Site de venda das camisetas com temas políticos, disponível em: <www.teetweets.com $\geq$. Acesso em: 24/01/2018. 
Por outro lado, desde as manifestações dos anos 1960, com a tomada do espaço público pelo movimento hippie, por uma juventude engajada e dissidente dos valores da ordem estabelecida, os corpos onde as imagens acampam se multiplicaram. $O$ uso de uma camiseta com um motivo político, tornou-se em si mesmo um ato político.
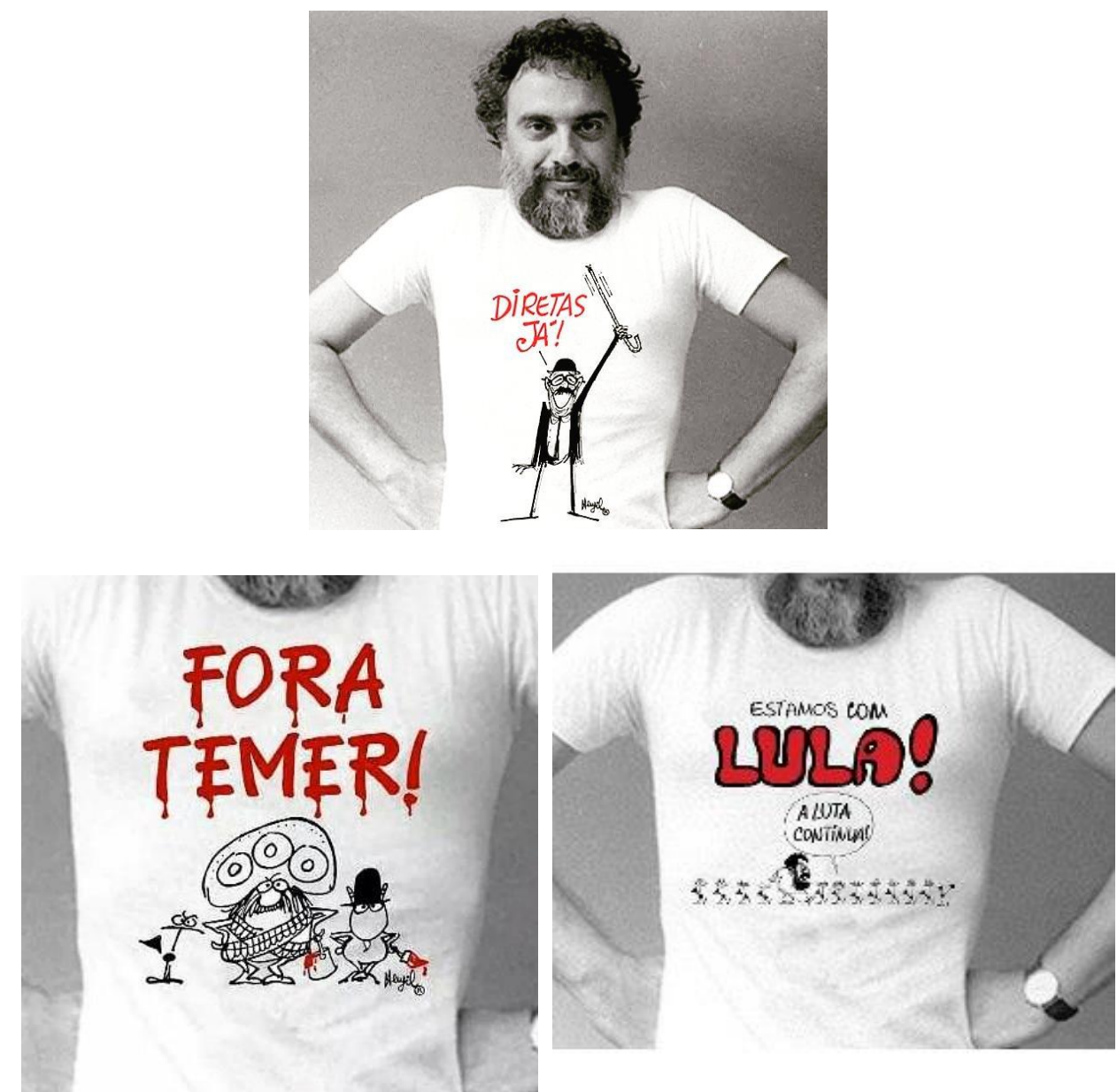

Fig. 14,15, 16: Primeira foto à esquerda, o cartunista Henfil (1944-1988) posa com a camiseta da campanha das “Diretas Já” (1984). Sua fotografia se replica em outros contextos, com outros modelos que simulam a imagem original. Disponível em: <https://www.facebook.com/lojadagrauna/>. Acesso em: 31 de janeiro de 2018.

\section{Considerações finais}

Esse artigo foi escrito para tentar responder a indagações que estão em curso nos meus estudos sobre fotografia pública e espaço público visual. Sem pretender esgotar, ou mesmo aprofundar a discussão teórica sobre espaço público e esfera pública, optei por sistematizar as posições em jogo atualmente na análise da imagem pública, como 
arte pública, como cultura pública, ou ainda, como resultado de uma dialética dos sujeitos históricos e seus espaços de convivência e disputas.

Dessa forma, em fins da década de 1940, a possibilidade do 'furo' de reportagem do jovem fotógrafo Flávio Damm, lançou Getúlio Vargas de volta à cena política pelas páginas das revistas ilustradas, elegendo-se presidente no pleito de 1950. Em pleno século XXI, Oprah Winfrey lança-se no espaço público visual - impresso e virtual - à corrida presidencial da Casa Branca.

Os dois estudos de caso aqui apresentados, não são passíveis de comparação; mais acertadamente, atuam como meios para se pensar distintas experiências históricas que configuram espaços públicos visuais, com dinâmicas e aspectos bem diferenciados. $O$ que nos faz concluir, que os conceitos podem ser ferramentas importantes para a compreensão do passado, mas se a cada momento os atualizarmos com os olhos do presente.

\section{Referências}

AZOULAY, Ariella. Civilimagination: a political ontology of photography.London. New York: Verso, 2012.

AZOULAY, Ariella. The civil contract of photography. New York: Zone Books, 2010.

BATCHEN, Geoffrey. Arder en deseos: la concepción de la fotografia. Barcelona: Gustavo Gilli, 2004.

BELTING, Hans. Antropología de la imagen. Buenos Aires: Katz Editores, 2012.

BENJAMIN, Walter. Pequena história da fotografia (1931) e teses sobre a história (1940). In: BENJAMIN, Walter. Obras escolhidas I. São Paulo: Brasiliense, 1987.

BENJAMIN, Walter. Sobre la fotografia. Edição e tradução de José Muñoz Millanes. Valência: Ed. Pre-Textos, 2008. 
BURGIN, Victor. Looking at photographs. In: BURGIN, Victor. Thinking photography. Londres: MacMillan Press, 1982, p.142-153.

COLEMAN, Kevin. The Right not to be Looked At. EIAL, v.26, n. 2, 2015.

COSTA, Helouise. Da fotografia de imprensa ao fotojornalismo. Acervo: revista do Arquivo Nacional, v.6, n.1-2, p. 55-74, 1993.

FOLHA DE SÃO PAULO. São Paulo, 7 de janeiro de 2018.

FLUSSER, Vilém. Why a philosophy of photography is necessary, towards a philosophy of photography. London: Reaktion Books, 2000.

HARIMAN, Robert; LUCAITES, John Louis. No caption needed: iconic photographs, public culture, and liberal democracy. Chicago: Chicago University Press, 2007.

HARIMAN, Robert; LUCAITES, John Louis. Public image: photography and civic spectatorship. Chicago; London: Chicago University Press, 2016.

KNAUSS, Paulo. Aproximações disciplinares: história, arte e imagem. Anos 90, Porto Alegre, v. 15, n. 28, p.151-168, dez. 2008.

KNAUSS, Paulo. $O$ desafio de fazer história com imagens: arte e cultura visual. Uberlândia: ArtCultura, v. 8, n. 12, p. 97-115, jan./jun., 2006.

KRACAUER, S. Ornamento da massa: ensaios. São Paulo: Cosac Naify, 2009.

KRAUSS, Rosalind. A note on photography and the simulacral. In: SQUIRES, Carol (Ed.) The critical image: essays on contemporary photography. Seattle: Bay Press, 1990, p. 15-27.

KRIEBEL, Sabine T. Theories of photography: short history. In: ELKINS, James (Ed.). Photography theory. New York; London: Routledge, 2007. p. 3-49.

LIMA, Solange Ferraz de; CARVALHO, Vania Carneiro. Circuitos e potencial icônico da fotografia: o caso Aylan Kurdi. Estudos Ibero-americanos, v.44, n.1, no prelo, 2018.

LINFIELD, Susie. The cruel radiance: photography and political violence. Chicago; London: University of Chicago Press, 2010.

LISSOVSKY, Mauricio. Pausas do destino: teoria, arte e história da fotografia. Rio de Janeiro: MauadX, 2014.

LUGON, Olivier. El estilo documental: de August Sander à Walker Evans (1920-1945). Salamanca: Ediciones Universidad de Salamanca, 2010. 
MAUAD, Ana Maria. Sobre as imagens na história, um balanço de conceitos e perspectivas.

Revista Maracanan, n. 14, p. 33-48, jan./jun. 2016.

MENESES, Ulpiano T.B. A fotografia como documento: Robert Capa e o miliciano abatido na Espanha - sugestões para um estudo histórico. Tempo, n. 14, p. 131-151, 2002.

MENESES, Ulpiano T. Bezerra de. Fontes visuais, cultura visual, história visual Balanço provisório, propostas cautelares.Revista Brasileira de História, v.23, n.45, p.11-36, 2003.

MENESES, Ulpiano T. Bezerra de. Rumo a uma história visual. In: MARTINS, José de Souza, ECKERT, Cornélia \& NOVAES, Sylvia Caiuby (Orgs.). $O$ imaginário e o poético nas ciências sociais. Bauru: EDUSC, 2005.

MITCHELL, W.J.T. What do pictures want? the lives and loves of images. Chicago: Chicago University Press, 2005. Cap. 16. Showing Seeing: a critique of visual culture, p. 336-356.

NEWHALL. Beaumont. Backward glance at documentary In: FEATHERSTONE, David (Ed.) Observations: essays on documentary photography. Carmel: The Friends of Photography Pub. 1984.

REVISTA DO GLOBO. Porto Alegre, 6 de novembro de 1948, ano XIX, n.470.

RITCHIN, Fred. Bending the frame: photojournalism, documentary, and the citizen. New York: Aperture, 2013.

SEKULLA, Allan. On the invention of photographic meaning. In: BURGIN, Victor. Thinking Photography. Londres: MacMillan Press, 1982. p. 84-109.

SONTAG, Susan. On Photography, New York: Farrar, Straus and Giroux, 1977.

SOUSA, Jorge Pedro. Uma história crítica do fotojornalismo ocidental. Chepecó: Ed. Grifos, 2000.

STIMSON, Blake. The pivot of the world: photography and its nation. Massachusetts: MIT Press, introduction, 2007. p. 1-58.

STRAUSS, David Levi. The documentary debate. In: Between the eyes: essays on photograghy and politics. New York: Apeture, p.3-11. 2003.

TAGG, John. The Currency of the Photograph. In: BURGIN, Victor. Thinking photography. Londres: MacMillan Press, 1982. p.110-141.

TAGG, John. The Burden of representation: essays on photographies and histories. Mineapolis: University of Minesota Press, 1988. 
Recebido em 15/12/2017 Aprovado em 28/02/2018

Universidade do Estado de Santa Catarina - UDESC Programa de Pós-Graduação em História - PPGH Revista Tempo e Argumento Volume 10 - Número 23 - Ano 2018 tempoeargumento@gmail.com 